Limnol. Rev. (2016) 16, 4: 185-197

\title{
A new bathymetric survey of the Suwałki Landscape Park lakes
}

\author{
Dariusz Borowiak ${ }^{1,2}$, Kamil Nowiński ${ }^{1}$, Katarzyna Grabowska ${ }^{1}$ \\ ${ }^{1}$ Department of Limnology, University of Gdańsk, Bażyńskiego 4, 80-952 Gdańsk, Poland, e-mail: geodb@univ.gda.pl (corresponding \\ author), geokamil@univ.gda.pl, katarzyna_grabowska@onet.pl \\ ${ }^{2}$ Limnological Station in Borucino, University of Gdańsk, 83-323 Kamienica Szlachecka, Poland, e-mail: geodb@univ.gda.pl
}

\begin{abstract}
The results of the latest bathymetric survey of 21 lakes in the Suwałki Landscape Park (SLP) are presented here. Measurements of the underwater lake topography were carried out in the years 2012-2013 using the hydroacoustic method (sonar Lawrence 480M). In the case of four lakes (Błędne, Pogorzałek, Purwin, Wodziłki) this was the first time a bathymetric survey had been performed. Field material was used to prepare bathymetric maps, which were then used for calculating the basic size and shape parameters of the lake basins. The results of the studies are shown against the nearly 90 year history of bathymetric surveying of the SLP lakes. In the light of the current measurements, the total area of the SLP lakes is over $634 \mathrm{hm}^{2}$ and its limnic ratio is $10 \%$. Lake water resources in the park were estimated at $143037.1 \mathrm{dam}^{3}$. This value corresponds to a retention index of $2257 \mathrm{~mm}$. In addition, studies have shown that the previous morphometric data are not very accurate. The relative differences in the lake surface areas ranged from -14.1 to $9.1 \%$, and in the case of volume - from -32.2 to $35.3 \%$. The greatest differences in the volume, expressed in absolute values, were found in the largest SLP lakes: Hańcza (1716.1 dam $\left.{ }^{3}\right)$, Szurpiły $\left(1282.0 \mathrm{dam}^{3}\right)$, Jaczno $\left(816.4 \mathrm{dam}^{3}\right)$, Perty $\left(427.1 \mathrm{dam}^{3}\right)$, Jegłówek $\left(391.2 \mathrm{dam}^{3}\right)$ and Kojle $\left(286.2\right.$ dam $\left.^{3}\right)$. The smallest disparities were observed with respect to the data obtained by the IRS (Inland Fisheries Institute in Olsztyn). The IMGW (Institute of Meteorology and Water Management) bathymetric measurements were affected by some significant errors, and morphometric parameters determined on their basis are only approximate.
\end{abstract}

Key words: underwater topography, morphometric parameters, lake form, water resources

\section{Introduction}

The parameters of the geometry of lake basins are the principal characteristics that differentiate lakes. They not only determine the physical dimensions of lake basins, their size and shape, but they also affect most physical, biological and chemical lake water properties. Geometric conditions of lakes determine energy and matter exchanges on the external border surfaces and their transfer within the lake. Thus, morphometric features of lakes also affect heat balance (Gorham 1964; Lange 1986), stratification and mictic type (Patalas 1960; Lathrop and Lille 1980; Gorhan and Boyce 1989), sediment dynamics (Håkanson 1977a; Blais and Kalff 1995), water residence time and flushing rate (Pasławski 1975; Johnson et al. 1978; Lerman and Hull 1987), distribution of nutrients and dissolved gases in a water column (Eberly 1964; Nuremberg 1995), light regime (Borowiak 2011), and consequently primary production (Fee 1979; Guildford et al. 1994) and qualitative characteristics of lake water (Nõges 2009; Stefanidis and Papastergiadou 2012).
Morphometric parameters are important elements of many limnological models and typologies; they are also used in lake management to estimate the natural resistance of lakes to external pressure from the catchment.

Lakes located within the Suwałki Landscape Park (SLP) were subjected to multidirectional limnological studies before 1939 (Pietkiewicz 1928; Śledziński 1928; Rühle 1932; Stangenberg 1936, 1937). At that time, the first bathymetric map of Lake Hańcza was prepared (Rühle 1932), and the depth details of 10 other lakes were collected (Stangenberg 1936, 1937), although these studies were only developed further in the 1960s by the Inland Fisheries Institute in Olsztyn (IRS). At that time, the IRS made a new bathymetric map of Lake Hańcza using the results of the pre-war works of Rühle and Stangenberg. In the 1970s and 1980s bathymetric maps of five SLP lakes not yet sounded were made: Kojle (Mickiewicz 1977) as well as Jaczno, Kluczysko, Jegłówek and Udziejek (OBiKŚ Suwałki unpubl.). Additionally, five previously surveyed lakes were re-meas- 
ured: Bocznel, Jaczno, Jegłówek, Kojle and Kopane (Jańczak 1999). Bathymetric mapping of the SLP lakes was completed in the first decade of the $21^{\text {st }} \mathrm{c}$., when Lakes Jegłóweczek and Linówek were measured (WIOŚ Białystok unpubl.), and the bathymetric map of Lake Hańcza was re-developed (Jozsa et al. 2008). By this time, full morphometric characteristics of 18 , mostly large, SLP lakes had been collected. Lakes Błędne, Purwin, Pogorzałek, Wodziłki and Lake Osińskiego still remained unexplored.

An overview of the morphometric documentation collected so far indicates that currently available data on the morphometry of the SLP lakes are very heterogeneous (Table 1), which considerably limits their practical use in limnological studies and lake management. Striking examples of the discrepancies are lakes Jaczno, Jegłówek and Perty. In the latter case the volume of the lake, depending on the data source, ranges from 1019.1 to 1384.5 dam $^{3}$ (Mickiewicz 1977; Jańczak 1999). Such significant discrepancies are the result of different, often very simplified measuring methods (grid squares of $50 \times 50$ in traditional surveys with a sounding line; a limited number of sounding tracks in the hydroacoustic surveys). There are also frequent cases when the authors make their own calculations of morphometric parameters based on ready bathymetric maps and then relate the obtained results to the primary source. Such practices mean that information on morphometry of the SLP lakes is uncertain, and sometimes simply unreliable.

The above-mentioned limitations in the use of the existing resources documenting morphometric relations of the SLP lakes as well as uncertainty about the reliability of these materials constituted a premise to re-develop the bathymetry of the lakes in the area. The overall objective of this project was to make credible bathymetric maps of the SLP lakes based on uniform measurement methods. Additional goals included: (i) verification and extension of the existing state of knowledge on the morphology of the SLP lakes, (ii) assessment of water resources of the park.

Table 1. Historical morphometric data of the Suwałki Landscape Park lakes from 1928 to 2008: Alt - geodetic elevation; $A_{0}-$ water surface area; $V$ - volume; $Z_{\max }$ - maximum depth; $L$ - maximum length; $B$ - maximum width; $S L D$ - shoreline development

\begin{tabular}{|c|c|c|c|c|c|c|c|c|}
\hline $\begin{array}{l}\text { Official * / common name } \\
\text { (other names) }^{\dagger}\end{array}$ & $\begin{array}{c}A l t \\
{[\mathrm{~m} \text { a.s.l. }]}\end{array}$ & $\begin{array}{c}A_{o} \\
{\left[\mathrm{hm}^{2}\right]}\end{array}$ & $\begin{array}{c}V \\
{\left[\mathrm{dam}^{3}\right]}\end{array}$ & $\begin{array}{l}Z_{\max } \\
{[\mathrm{m}]}\end{array}$ & $\begin{array}{c}L \\
{[\mathrm{~m}]}\end{array}$ & $\begin{array}{c}B \\
{[\mathrm{~m}]}\end{array}$ & $\begin{array}{l}S L D \\
\text { [d.u.] }\end{array}$ & References \\
\hline Błędne / Błędne & - & 2.1 & - & - & - & - & - & Choiński (1991) \\
\hline Muliste $^{\dagger}$ & - & 2.3 & - & $<10$ & - & - & - & Kołodziejczyk (1994) \\
\hline Bocznel / Boczniel & - & 18.6 & - & 4.3 & - & - & 1.53 & Stangenberg (1936) \\
\hline Boczne & 230.0 & 18.6 & - & 4.3 & 1300 & 100 & - & Gieysztorowa (1953) \\
\hline \multirow[t]{3}{*}{ Bocznel Filipowski } & 227.0 & 18.2 & 324.1 & 4.3 & 1520 & 200 & 2.10 & IRS (unpubl.) ${ }^{\ddagger}$ \\
\hline & 227.6 & 16.0 & - & - & - & - & - & Choiński (1991) \\
\hline & 229.0 & 16.5 & 165.0 & 1.8 & 1520 & 175 & 2.17 & Jańczak (1999) \\
\hline \multirow[t]{5}{*}{ Gulbin / Gulbin } & - & 7.6 & - & 9.4 & - & - & 1.23 & Stangenberg (1937) \\
\hline & 149.0 & 9.0 & - & $>5$ & 500 & 220 & - & Gieysztorowa (1953) \\
\hline & 148.5 & 7.4 & 265.8 & 9.4 & 475 & 205 & 1.20 & IRS (unpubl.) \\
\hline & 147.6 & 7.4 & 268.0 & 8.8 & 475 & 200 & - & Mickiewicz (1977) \\
\hline & - & 7.5 & - & - & - & - & - & Choiński (1991) \\
\hline \multirow[t]{9}{*}{ Hańcza / Hańcza } & 227.2 & 295.0 & - & $>100$ & 4500 & 1000 & - & Pietkiewicz (1928) \\
\hline & - & 285.0 & - & 104.5 & - & - & - & Śledziński (1928) \\
\hline & 227.2 & 296.3 & 124400.0 & 108.0 & 4535 & 1175 & 2.08 & Rühle (1930) \\
\hline & - & 305.8 & - & 108.5 & - & - & 1.95 & Stangenberg (1936) \\
\hline & 227.2 & 305.8 & - & 108.5 & 4500 & 1185 & - & Gieysztorowa (1953) \\
\hline & 229.0 & 311.4 & 120364.1 & 108.5 & 4525 & 1175 & 1.88 & IRS (unpubl.) \\
\hline & 227.3 & 291.5 & - & - & - & - & - & Choiński (1991) \\
\hline & - & - & - & 106.1 & - & - & - & Choiński and Skowron (1998) \\
\hline & 227.3 & 304.4 & 117620.2 & 112.0 & 4530 & 1172 & - & Jozsa et al. (2008) \\
\hline Jaczno / Jaczno & 163.0 & 34.0 & - & - & 1300 & 600 & - & Gieysztorowa (1953) \\
\hline \multirow[t]{4}{*}{ Jaczne } & 163.8 & 53.0 & 4200.0 & 27.0 & - & - & - & Byczkowski (1980) \\
\hline & 163.0 & 39.7 & 3964.6 & 25.0 & 1840 & 600 & 2.24 & OBiKŚ Suwałki (unpubl.) \\
\hline & 163.9 & 41.0 & - & - & - & - & - & Choiński (1991) \\
\hline & 163.8 & 41.0 & 4797.0 & 29.6 & 1662 & 480 & 2.13 & Jańczak (1999) \\
\hline Jegłóweczek / Jeglóweczek & 187.0 & 3.5 & - & - & 300 & 100 & - & Pietkiewicz (1928) \\
\hline \multirow[t]{3}{*}{ Jeglóweczek } & - & 1.1 & - & - & - & - & - & Choiński (1991) \\
\hline & - & 1.5 & - & $<10$ & - & - & - & Kołodziejczyk (1994) \\
\hline & 185.2 & 1.6 & 60.9 & 8.2 & 230 & 100 & 1.3 & WIOŚ Białystok (unpubl.) \\
\hline Jegłówek / Jeglówek & 187.0 & 19.0 & - & - & 900 & 250 & - & Pietkiewicz (1928) \\
\hline \multirow{4}{*}{ Jeglówek } & 187.0 & 19.0 & - & - & 900 & 250 & - & Gieysztorowa (1953) \\
\hline & 185.1 & 13.5 & - & 26.5 & - & - & - & Choiński (1991) \\
\hline & 187.1 & 19.2 & 1444.0 & 18.1 & 963 & 395 & 1.66 & Jańczak (1999) \\
\hline & 187.0 & 19.6 & 1878.6 & 26.6 & 952 & 395 & 1.68 & OBiKŚ Suwałki (unpubl.) \\
\hline
\end{tabular}




\begin{tabular}{|c|c|c|c|c|c|c|c|c|}
\hline $\begin{array}{l}\text { Official }{ }^{*} / \text { common name } \\
\text { (other names) }^{\dagger}\end{array}$ & $\begin{array}{c}\text { Alt } \\
{[\mathrm{m} \text { a.s.I.] }}\end{array}$ & $\begin{array}{c}A_{0} \\
{\left[\mathrm{hm}^{2}\right]}\end{array}$ & $\begin{array}{c}V \\
{\left[\mathrm{dam}^{3}\right]}\end{array}$ & $\begin{array}{l}Z_{\max } \\
{[\mathrm{m}]}\end{array}$ & $\begin{array}{c}L \\
{[\mathrm{~m}]}\end{array}$ & $\begin{array}{c}B \\
{[\mathrm{~m}]}\end{array}$ & $\begin{array}{l}S L D \\
\text { [d.u.] }\end{array}$ & References \\
\hline $\begin{array}{l}\text { Kameduł / Kamenduł } \\
\text { Kamendul }\end{array}$ & $\begin{array}{c}- \\
- \\
161.0 \\
160.1 \\
161.0\end{array}$ & $\begin{array}{c}- \\
25.7 \\
19.0 \\
25.5 \\
26.0\end{array}$ & $\begin{array}{c}- \\
- \\
- \\
1730.5 \\
-\end{array}$ & $\begin{array}{c}14.0 \\
24.5 \\
20-25 \\
24.5 \\
-\end{array}$ & $\begin{array}{c}- \\
- \\
900 \\
950 \\
-\end{array}$ & $\begin{array}{c}- \\
- \\
400 \\
420 \\
-\end{array}$ & $\begin{array}{l}- \\
- \\
- \\
1.28 \\
-\end{array}$ & $\begin{array}{l}\text { Śledziński (1928) } \\
\text { Stangenberg (1937) } \\
\text { Gieysztorowa (1953) } \\
\text { IRS (unpubl.) } \\
\text { Choiński (1991) }\end{array}$ \\
\hline $\begin{array}{l}\text { Kluczysko / Kluczysko } \\
\text { Jeglóweczek } \\
\text { Kulczyckie } \\
\text { Tchleczysko } \\
\text { Tchliczysko }\end{array}$ & $\begin{array}{c}186.8 \\
187.0 \\
187.0 \\
-\end{array}$ & $\begin{array}{l}4.6 \\
3.5 \\
3.6 \\
3.0\end{array}$ & $\begin{array}{c}- \\
- \\
212.1 \\
-\end{array}$ & $\begin{array}{c}- \\
- \\
13.6 \\
13.6\end{array}$ & $\begin{array}{c}400 \\
300 \\
325 \\
-\end{array}$ & $\begin{array}{c}150 \\
100 \\
132 \\
-\end{array}$ & $\begin{array}{c}- \\
- \\
1.37 \\
-\end{array}$ & $\begin{array}{l}\text { Pietkiewicz (1928) } \\
\text { Gieysztorowa (1953) } \\
\text { OBiKŚ Suwałki (unpubl.) } \\
\text { Choiński (1991) }\end{array}$ \\
\hline Kojle / Kojle & $\begin{array}{c}149.0 \\
148.1 \\
- \\
- \\
149.2 \\
\end{array}$ & $\begin{array}{l}25.0 \\
15.4 \\
15.4 \\
17.5 \\
16.1\end{array}$ & $\begin{array}{c}- \\
1394.0 \\
1351.0 \\
- \\
1754.9 \\
\end{array}$ & $\begin{array}{c}20-25 \\
33.0 \\
33.0 \\
- \\
27.5 \\
\end{array}$ & $\begin{array}{c}900 \\
560 \\
- \\
- \\
655\end{array}$ & $\begin{array}{c}500 \\
425 \\
- \\
- \\
390\end{array}$ & $\begin{array}{c}- \\
- \\
1.47 \\
- \\
1.34\end{array}$ & $\begin{array}{l}\text { Gieysztorowa (1953)\# } \\
\text { Mickiewicz (1977) } \\
\text { Bajkiewicz-Grabowska (1994) } \\
\text { Choiński (1991) } \\
\text { Jańczak (1999) }\end{array}$ \\
\hline $\begin{array}{l}\text { Kopane / Kopane } \\
\text { Kopańce }\end{array}$ & $\begin{array}{c}178.5 \\
- \\
- \\
178.5 \\
178.8 \\
178.8 \\
179.0 \\
- \\
178.8 \\
\end{array}$ & $\begin{array}{c}13.0 \\
- \\
15.2 \\
13.0 \\
15.1 \\
15.1 \\
12.5 \\
13.0 \\
14.5 \\
\end{array}$ & $\begin{array}{c}- \\
- \\
- \\
- \\
821.0 \\
851.8 \\
- \\
- \\
1058.5\end{array}$ & $\begin{array}{c}- \\
17.5 \\
18.7 \\
15-20 \\
18.7 \\
18.7 \\
- \\
8.5 \\
17.4 \\
\end{array}$ & $\begin{array}{c}800 \\
- \\
- \\
800 \\
805 \\
805 \\
- \\
- \\
752\end{array}$ & $\begin{array}{c}200 \\
- \\
- \\
200 \\
290 \\
290 \\
- \\
- \\
278\end{array}$ & $\begin{array}{c}- \\
- \\
1.43 \\
- \\
1.43 \\
1.40 \\
- \\
- \\
1.48\end{array}$ & $\begin{array}{l}\text { Pietkiewicz (1928) } \\
\text { Śledziński (1928) } \\
\text { Stangenberg (1937) } \\
\text { Gieysztorowa (1953) } \\
\text { IRS (unpubl.) } \\
\text { OBiKŚ Suwałki (unpubl.) } \\
\text { Choiński (1991) } \\
\text { Ozimek and Rybak (1994) } \\
\text { Jańczak (1999) }\end{array}$ \\
\hline $\begin{array}{l}\text { Krejwelek / Krejwelek } \\
\text { Krajwelek } \\
\text { Krejwel } \\
\text { Okrągłek }\end{array}$ & $\begin{array}{c}- \\
- \\
148.0 \\
146.3 \\
146.3 \\
- \\
- \\
\end{array}$ & $\begin{array}{c}- \\
9.6 \\
8.5 \\
9.6 \\
9.5 \\
8.5 \\
15.8 \\
\end{array}$ & $\begin{array}{c}- \\
- \\
- \\
316.4 \\
316.0 \\
- \\
474.0\end{array}$ & $\begin{array}{c}5.0 \\
7.2 \\
- \\
7.2 \\
6.0 \\
- \\
6.0 \\
\end{array}$ & $\begin{array}{c}- \\
- \\
600 \\
570 \\
570 \\
- \\
-\end{array}$ & $\begin{array}{c}- \\
- \\
250 \\
220 \\
220 \\
- \\
-\end{array}$ & $\begin{array}{l}- \\
1.37 \\
- \\
1.38 \\
- \\
- \\
-\end{array}$ & $\begin{array}{l}\text { Śledziński (1928) } \\
\text { Stangenberg (1937) } \\
\text { Gieysztorowa (1953) } \\
\text { IRS (unpubl.) } \\
\text { Mickiewicz (1977) } \\
\text { Choiński (1991) } \\
\text { Bajkiewicz-Grabowska (1994) }\end{array}$ \\
\hline Not listed / Linówek & $\begin{array}{c}- \\
- \\
- \\
199.7\end{array}$ & $\begin{array}{l}2.9 \\
2.2 \\
2.9 \\
2.6\end{array}$ & $\begin{array}{c}- \\
- \\
- \\
70.0\end{array}$ & $\begin{array}{c}6.5 \\
- \\
6.9 \\
5.6\end{array}$ & $\begin{array}{c}- \\
- \\
- \\
235\end{array}$ & $\begin{array}{c}- \\
- \\
- \\
150\end{array}$ & $\begin{array}{l}1.08 \\
- \\
- \\
1.09\end{array}$ & $\begin{array}{l}\text { Stangenberg (1936) } \\
\text { Choiński (1991) } \\
\text { Kołodziejczyk (1994) } \\
\text { WIOŚ Białystok (unpubl.) }\end{array}$ \\
\hline $\begin{array}{l}\text { Okrągłe / Okrągłe } \\
\text { Okrągłe Kleszczowieckie }\end{array}$ & $\begin{array}{c}- \\
149.0 \\
147.0 \\
147.1 \\
146.9 \\
- \\
147.1 \\
\end{array}$ & $\begin{array}{l}14.2 \\
14.6 \\
15.8 \\
15.8 \\
15.0 \\
17.4 \\
15.7 \\
\end{array}$ & $\begin{array}{c}- \\
- \\
703.5 \\
689.5 \\
- \\
817.0 \\
715.5 \\
\end{array}$ & $\begin{array}{c}8.0 \\
>5 \\
8.0 \\
7.0 \\
- \\
8.0 \\
8.0\end{array}$ & $\begin{array}{c}- \\
800 \\
638 \\
630 \\
- \\
- \\
625\end{array}$ & $\begin{array}{c}- \\
350 \\
364 \\
360 \\
- \\
- \\
350\end{array}$ & $\begin{array}{l}1.19 \\
- \\
1.10 \\
- \\
- \\
1.16 \\
1.07\end{array}$ & $\begin{array}{l}\text { Stangenberg (1937) } \\
\text { Gieysztorowa (1953) } \\
\text { IRS (unpubl.) } \\
\text { Mickiewicz (1977) } \\
\text { Choiński (1991) } \\
\text { Bajkiewicz-Grabowska (1994) } \\
\text { Jańczak (1999) }\end{array}$ \\
\hline $\begin{array}{l}\text { Perty / Perty } \\
\text { Pierty }\end{array}$ & $\begin{array}{c}- \\
149.0 \\
148.0 \\
148.1 \\
148.3 \\
- \\
148.8 \\
\end{array}$ & $\begin{array}{l}20.2 \\
25.0 \\
20.0 \\
20.0 \\
20.0 \\
19.7 \\
20.4 \\
\end{array}$ & $\begin{array}{c}- \\
- \\
1341.0 \\
1384.5 \\
- \\
1183.0 \\
1019.1 \\
\end{array}$ & $\begin{array}{c}31.0 \\
20-25 \\
31.0 \\
32.0 \\
- \\
31.0 \\
31.0 \\
\end{array}$ & $\begin{array}{c}- \\
900 \\
900 \\
900 \\
- \\
- \\
900\end{array}$ & $\begin{array}{c}- \\
500 \\
400 \\
400 \\
- \\
- \\
400\end{array}$ & $\begin{array}{c}1.73 \\
- \\
1.70 \\
- \\
- \\
1.65 \\
1.72\end{array}$ & $\begin{array}{l}\text { Stangenberg (1937) } \\
\text { Gieysztorowa (1953)\# } \\
\text { IRS (unpubl.) } \\
\text { Mickiewicz (1977) } \\
\text { Choiński (1991) } \\
\text { Bajkiewicz-Grabowska (1994) } \\
\text { Jańczak (1999) }\end{array}$ \\
\hline $\begin{array}{l}\text { Pogorzałek / Pogorzełek } \\
\text { Cisówek }\end{array}$ & $\begin{array}{c}246.0 \\
- \\
- \\
\end{array}$ & $\begin{array}{l}4.0 \\
5.0 \\
6.0 \\
\end{array}$ & $\begin{array}{l}- \\
- \\
-\end{array}$ & $\begin{array}{c}- \\
- \\
<10\end{array}$ & $\begin{array}{l}- \\
- \\
-\end{array}$ & $\begin{array}{l}- \\
- \\
-\end{array}$ & $\begin{array}{l}- \\
- \\
-\end{array}$ & $\begin{array}{l}\text { Gieysztorowa (1953) } \\
\text { Choiński (1991) } \\
\text { Kołodziejczyk } 1994\end{array}$ \\
\hline $\begin{array}{l}\text { Postawelek / Postawelek } \\
\text { Lizdejki }\end{array}$ & $\begin{array}{c}- \\
141.0 \\
145.6 \\
145.6 \\
-\end{array}$ & $\begin{array}{l}3.5 \\
2.5 \\
3.5 \\
3.4 \\
2.2\end{array}$ & $\begin{array}{c}- \\
- \\
91.9 \\
91.8 \\
-\end{array}$ & $\begin{array}{l}5.3 \\
- \\
5.3 \\
4.8 \\
-\end{array}$ & $\begin{array}{c}- \\
300 \\
260 \\
250 \\
-\end{array}$ & $\begin{array}{c}- \\
200 \\
200 \\
200 \\
-\end{array}$ & $\begin{array}{l}1.08 \\
- \\
1.08 \\
- \\
-\end{array}$ & $\begin{array}{l}\text { Stangenberg (1937) } \\
\text { Gieysztorowa (1953) } \\
\text { IRS (unpubl.) } \\
\text { Mickiewicz (1977) } \\
\text { Choiński (1991) }\end{array}$ \\
\hline Przechodnie / Przechodnie & $\begin{array}{c}- \\
147.0 \\
147.0 \\
146.0 \\
146.0 \\
-\end{array}$ & $\begin{array}{l}25.9 \\
22.0 \\
25.4 \\
25.5 \\
21.0 \\
28.3\end{array}$ & $\begin{array}{c}- \\
- \\
848.6 \\
832.1 \\
- \\
944.0\end{array}$ & $\begin{array}{c}6.3 \\
>5 \\
6.3 \\
5.4 \\
- \\
6.3\end{array}$ & $\begin{array}{c}- \\
800 \\
820 \\
830 \\
- \\
-\end{array}$ & $\begin{array}{c}- \\
500 \\
495 \\
490 \\
- \\
-\end{array}$ & $\begin{array}{l}1.21 \\
- \\
1.20 \\
- \\
- \\
1.17\end{array}$ & $\begin{array}{l}\text { Stangenberg (1937) } \\
\text { Gieysztorowa (1953) } \\
\text { IRS (unpubl.) } \\
\text { Mickiewicz (1977) } \\
\text { Choiński (1991) } \\
\text { Bajkiewicz-Grabowska (1994) }\end{array}$ \\
\hline
\end{tabular}




\begin{tabular}{|c|c|c|c|c|c|c|c|c|}
\hline $\begin{array}{l}\text { Official* / common name } \\
\text { (other names) }^{\dagger}\end{array}$ & $\begin{array}{c}\text { Alt } \\
{[\mathrm{m} \text { a.s.I.] }}\end{array}$ & $\begin{array}{c}A_{o} \\
{\left[\mathrm{hm}^{2}\right]}\end{array}$ & $\begin{array}{c}V \\
{\left[\mathrm{dam}^{3}\right]}\end{array}$ & $\begin{array}{l}Z_{\max } \\
{[\mathrm{m}]}\end{array}$ & $\begin{array}{c}L \\
{[\mathrm{~m}]}\end{array}$ & $\begin{array}{c}B \\
{[\mathrm{~m}]}\end{array}$ & $\begin{array}{l}S L D \\
\text { [d.u.] }\end{array}$ & References \\
\hline Not listed / Purwin & 152.0 & 1.3 & - & - & 175 & 75 & - & Gieysztorowa (1953) \\
\hline Kleszczówek & 148.9 & 1.1 & - & - & - & - & - & Mickiewicz (1977) \\
\hline Kojle Małe & - & 1.2 & - & - & - & - & - & Choiński (1991) \\
\hline Purwinek & - & 1,2 & - & 4.0 & - & - & - & Kołodziejczyk (1994) \\
\hline \multirow[t]{6}{*}{ Szurpiły / Szurpiły } & - & - & - & 41.0 & - & - & - & Śledziński (1928) \\
\hline & - & 81.0 & - & 46.8 & 1950 & - & 2.27 & Stangenberg (1936) \\
\hline & 182.5 & 89.5 & - & 46.8 & 1900 & 500 & - & Gieysztorowa (1953) \\
\hline & 183.1 & 80.9 & 8168.8 & 46.8 & 2050 & 775 & 2.19 & IRS (unpubl.) \\
\hline & 182.8 & 82.0 & - & - & - & - & - & Choiński (1991) \\
\hline & 183.1 & 80.9 & 8168.8 & 46.2 & 2050 & 775 & 2.19 & Jańczak (1999) \\
\hline Udziejek / Udziejek & 154.0 & 5.0 & - & - & 300 & 200 & - & Gieysztorowa (1953) \\
\hline Uzdziejek & 154.2 & 5.2 & - & - & - & - & - & Mickiewicz (1977) \\
\hline \multirow[t]{3}{*}{ Uździejek } & - & 6.0 & - & - & - & - & - & Choiński (1991) \\
\hline & - & 5.0 & - & 6.0 & - & - & - & Ozimek and Rybak (1994) \\
\hline & 154.0 & 6.1 & 228.9 & 7.2 & 348 & 272 & 1.14 & OBiKŚ Suwałki (unpubl.) \\
\hline Not listed / Wodziłki & 175.7 & 4.0 & - & - & 300 & 150 & - & Pietkiewicz (1928) \\
\hline \multirow[t]{3}{*}{ w Wodziłkach } & 175.7 & 4.0 & - & - & 300 & 150 & - & Gieysztorowa (1953) \\
\hline & - & 2.0 & - & - & - & - & - & Choiński (1991) \\
\hline & - & 4.5 & - & $<10$ & - & - & & Kołodziejczyk (1994) \\
\hline
\end{tabular}

* - official names of the lakes according to GUGiK (2006); ${ }^{\dagger}$ - other names of the lakes listed in the table are given in alphabetical order, not according to references; ${ }^{*}$ - unpublished bathymetric maps and morphometric cards compiled by IRS (Inland Fisheries Institute in Olsztyn) in the years 1960-1968 based on field measurements conducted by M. Stangenberg in 1934; ${ }^{*}$ - lakes Kojle and Perty together.

\section{Research area}

The morphometric study covered lakes located within the Suwałki Landscape Park (SLP) with the exception of its buffer zone. The selection of research objects was guided by the size criterion. The catalogue of Polish lakes, published by the Polish Geographical Society in 1952-1953 (Majdanowski 1954) states that a lake is a natural reservoir with a minimum area of $1.0 \mathrm{hm}^{2}$. Such a surface threshold was adopted in this study, which only selected lakes larger than $1.0 \mathrm{hm}^{2}$. As a result of the analysis of available documentary material (Gieysztorowa 1953; Choiński 1991; Jańczak 1999), 22 lakes that meet the above criteria were initially chosen for the morphometric studies. The list did not include Turtul Pond (an anthropogenic water body) or Lake Osińskiego, which, according to the inventory by Choiński (1991), has an area of $1.0 \mathrm{hm}^{2}$. Subsequent detailed cartometric measurements, conducted after the completion of fieldwork, showed that this lake is larger $\left(1.24 \mathrm{hm}^{2}\right)$. Additionally, Lake Hańcza, the largest lake in the SLP, was excluded from the initial list as bathymetric research had been conducted as recently as 20102011 (Popielarczyk and Templin 2014; Popielarczyk et al. 2015). Thus, the final field measurements included 21 lakes. Their spatial distribution is shown in Figure 1. General morphometric characteristics of the SLP lakes also include the results of the latest bathymetric measurements of Lake Hańcza.

\section{Methods}

Measurements of the underwater topography of the SLP lakes were carried out in two stages. In the first stage, conducted in 2012, a total of 13 lakes were surveyed. The essential part of the work took place in June (2 lakes) and August (10 lakes), and in November the work continued only on Lake Szurpiły. The second stage, during which a further eight lakes were measured, was completed in May of the following year.

The measurements were performed from a pneumatic boat equipped with an echo sounder, Lawrence $480 \mathrm{M}$, and an external GPS receiver/antenna (Lawrence LGC-2000). A single-beam transducer with a frequency of $200 \mathrm{kHz}$ and a wide cone angle $\left(20^{\circ}\right)$ was mounted on the boat transom and immersed to a depth of $0.5 \mathrm{~m}$. This kit allows measurements on water objects to be made to a depth of $300 \mathrm{~m}$.

In order to limit the impact of boat instability on the measurements of depth, the maximum boat speed did not exceed $2.5-3.0 \mathrm{~km}$ per hour $\left(\sim 0.7-0.8 \mathrm{~m} \mathrm{~s}^{-1}\right)$, and the measurements were taken at a wind velocity below $3 \mathrm{~m} \mathrm{~s}^{-1}$.

Sounding tracks were closed lines, as much as possible running parallel to the lakeshore, and concentrically to the central point of the lake or, in the case of multi-basin lakes, to lake basin (e.g. Jaczno). Sounding tracks were spaced at approx. 20-30 metres. When sounding lakes with an area greater than $10 \mathrm{ha}$, the distance between tracks was increased to 40-50 metres. Such a measuring grid was supplemented by an additional longitudinal profile as well as several cross-sec- 


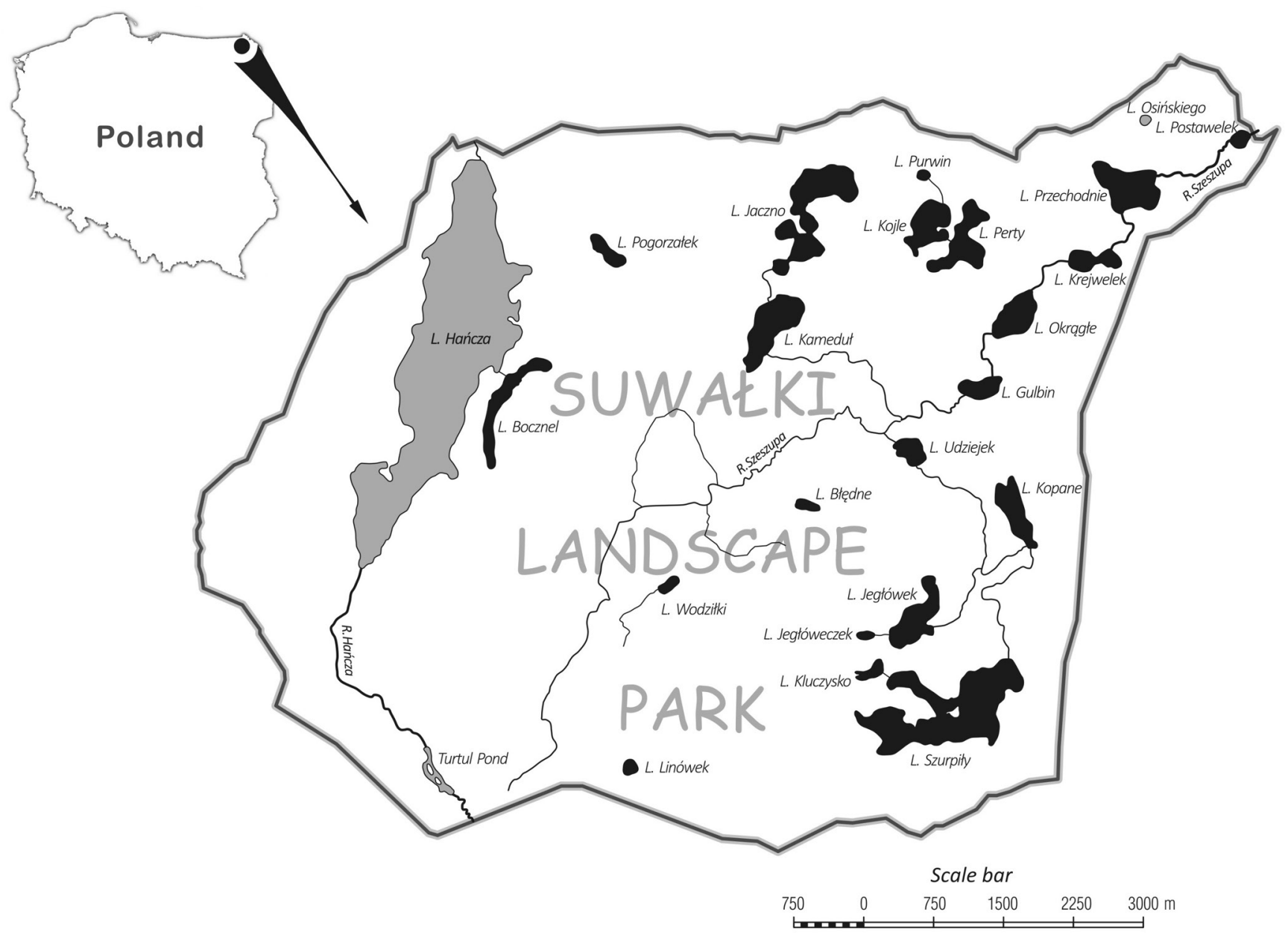

Fig. 1. Distribution of studied lakes (in black) within the Suwałki Landscape Park

tions. In places of significant bottom depressions, the measurement grid was thickened in order to precisely determine the point of maximum depth. In places where the maximum depths were identified with a sonar, the obtained values were confirmed by performing measurements using a sounding line (i.e. lead line). Differences in maximum depth using both methods did not exceed $\pm 15 \mathrm{~cm}$.

Lake water level naturally fluctuates as a result of seasonal and long-term changes in the elements of the water balance. Direct measurement of the geodetic altitude of water surfaces during depth measurement was not possible because water level observations are not conducted on these lakes. Hydrological conditions during the survey period were determined indirectly by analysing long-term water level fluctuations in Lake Hańcza. For the period 1971-2015 the zone of mean water levels of Lake Hańcza is determined by a geodetic altitude ranging from 227.39 to $227.58 \mathrm{~m}$ a.s.l. The average multi-year value is $227.54 \mathrm{~m}$ a.s.l. During the measurements carried out in August and November 2012, the water surface of Lake Hańcza was located at a height of 227.51-227.56 m a.s.l., which corresponds to average water levels. In June 2012 and in May 2013 the water level in Lake Hańcza exceeded the upper limit of the zone of mean water levels by, respectively, 8 and $11 \mathrm{~cm}$. At that time the hydrological conditions of the lakes showed increased retention. It can be assumed that the water level in the subsequently probed lakes (Gulbin, Pogorzałek, Błędne, Bocznel, Jegłóweczek, Jegłówek, Kluczysko, Linówek, Purwin and Udziejek) was higher than the average by about $10 \mathrm{~cm}$.

The documentary material collected during the field research was used to make bathymetric maps. Initially, these maps were developed in the program DrDepth ver. 5.0, while their final graphical visualisation was prepared in the program CorelDraw ver. 8 . The lake shorelines were dotted from orthophotomaps. An example of a ready bathymetric map, made for Lake Szurpiły, is presented in Figure 2.

Depending on the size of lakes, bathymetric maps were made in different scales. Lakes smaller than $10 \mathrm{hm}^{2}$ were mapped in the scale 1:2500, for lakes of 


\section{Lake Szurpiły}

Geographical location:

Lat. $54^{\circ} 13.77^{\prime} \mathrm{N} \quad$ Long. $22^{\circ} 53.86^{\prime} \mathrm{E}$ Macroregion: Lithuanian Lakeland

Mesoregion: East Suwatki Lakeland

Microregion: Jeleniewo Hills

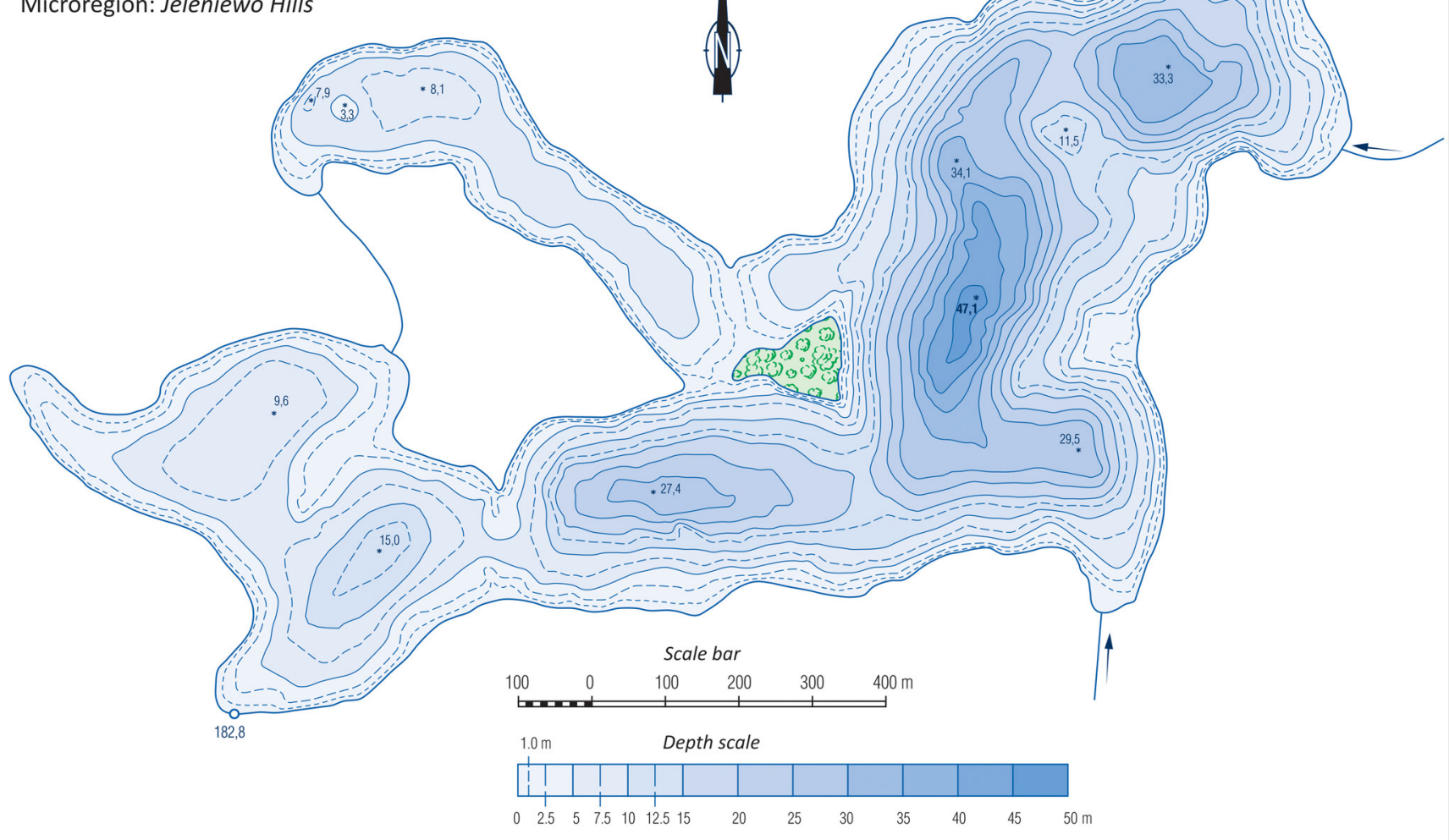

Fig. 2. Bathymetric map of Lake Szurpiły

10-25 hm² the scale of 1:5000 was adopted, and for the lakes larger than $25 \mathrm{hm}^{2}$ the scale of 1:10000 was used.

Calculation of the size and shape parameters of lake basins was made in accordance with the guidelines issued by Håkanson (1981). Slightly different criteria were adopted only when determining the maximum length of the lakes. The aim of using new rules was to objectify the measurements and assign a given parameter a clearly defined value. In the new terms, the maximum length of the lake is a median line connecting the two most distant points on the lakeshore. In theoretical terms, the median line is defined by the locus of the centres of an infinite set of circles inscribed in the contour of the lake. In practice, the theoretical median line was reduced to a series of straight line segments between the selected equidistant points. It was also assumed that the maximum length line (similarly to the maximum width line) can cross islands.

\section{Results}

In the Suwałki Landscape Park, which occupies $63.38 \mathrm{~km}^{2}$, there are 23 natural lakes larger than $1 \mathrm{hm}^{2}$. In the years 2010-2013 detailed measurements of underwater topography were conducted and new bathymetric maps were made for 22 of them. The survey results are summarised in Table 2, showing the basic parameters of the geometry of the studied lake basins. The total water surface of these lake is $633.13 \mathrm{hm}^{2}$. Considering Lake Osińskiego, which was not surveyed, the total area of natural water bodies in the SLP is over $634 \mathrm{hm}^{2}$ and its limnic ratio is $10 \%$.

The SLP lakes are relatively small. Their average surface area is 28.78 , and the median value is just 11.90 $\mathrm{hm}^{2}$. The surface area above the average refers only to three lakes (Hańcza, Szurpiły, Jaczno), which together account for about $68 \%$ of the total lake water of the park.

The maximum depths of the surveyed lakes range from 3.9 (Bocznel) to $105.6 \mathrm{~m}$ (Hańcza). Ten of the lakes have a maximum depth of over $10 \mathrm{~m}$, and an- 
other eight - over $5 \mathrm{~m}$. Thus, these are deep and medium deep lakes $(M e=8.7 \mathrm{~m})$. Of the four lakes for which bathymetric maps were prepared for the first time, the deepest is Pogorzałek $(17.6 \mathrm{~m})$. According to the depth criterion, this lake occupies the ninth place on the list of the deepest lakes in the SLP. The maximum depths of the other newly surveyed lakes are 4.3-5.4 m.

Overall lake retention of the SLP is estimated at $143037.1 \mathrm{dam}^{3}$. This value corresponds to the retention index of $2257 \mathrm{~mm}$, and is the equivalent of nearly four-year normal precipitation established for the years 1981-2010 at the weather station in Suwałki (597 mm). Almost $83 \%$ of these resources is accumulated in the largest lake in the park - Lake Hańcza. Lake Szurpiły, the second lake in terms of volume, holds $6.6 \%$ of the water in the park.

The dominant role of Lake Hańcza in shaping water resources of the park is also reflected in the values of mean depth. The mean depth of the SLP lakes, calculated as the quotient of the total volume of lakes to their total area is as high as $22.6 \mathrm{~m}$. However, only the mean depth of Lake Hańcza is greater than the value calculated in that way. Mean depths greater than $9.0 \mathrm{~m}$ are recorded in only four lakes (Szurpiły, Jegłówek, Jaczno,
Kojle), and half of the SLP lakes have a mean depth of less than $3.9 \mathrm{~m}$ (Table 2).

Other lake size parameters shown in Table 2 are interdependent with the lake surfaces. The surface and the parameters are tied by strong and very strong positive relationships that describe the determination coefficients in the range from 0.82 (maximum effective width) to 0.98 (maximum effective length).

The basins of most of the studied lakes are convex (types $C x$ and $C x-S C x$ ) or slightly convex (types $S C x-C x$ and $S C x$ ). These types are characteristic of all very deep and deep lakes of the SLP. Most convex are the basins of Lakes Szurpily and Perty, respectively, Cxmi and Cxme. Lake Hańcza's basin is described as an $p$-mSCxmi type (Fig. 3B). The basins of lakes of medium depth $\left(5<z_{\max }<10 \mathrm{~m}\right)$ are generally linear forms (types $L$ and $L-C$ ). However, the deepest lakes in this group (Gulbin, Jegłóweczek) have regular, slightly convex forms (SCXme and SCXmi) (Fig. 3C). The shallowest lakes in the park exhibit the greatest diversity of their basin forms. The basins of these lakes have a concave form (Purwin - type $m \mathrm{Cme}$ ), linear (Postawelek - type Lmi), and slightly convex (Błędne - type pSCXmi; Bocznel - type mSCxmi) (Fig. 3D).

Table 2. Geographical coordinates of the maximum depth point, mean geodetic elevation of lake surface above sea level (Alt), lake basin form, and the basic morphometric parameters of the Suwałki Landscape Park lakes: $A_{s}$ - total lake area; $A_{0}$ - water surface area; $V$ - volume; $Z_{\text {max }}$ - maximum depth; $Z$ - mean depth; $L$ - maximum length; $B$ - maximum width; $L_{e f}$ - maximum effective length; $B_{e f}$ - maximum effective width; $S L$ - shoreline length

\begin{tabular}{|c|c|c|c|c|c|c|c|c|c|c|c|c|c|c|}
\hline Lake & N. Lat. & Long. & $\begin{array}{c}\text { Alt } \\
\text { [m.a.s.I.] }\end{array}$ & $\begin{array}{c}A_{s} \\
{\left[\mathrm{hm}^{2}\right]}\end{array}$ & $\begin{array}{c}A_{o} \\
{\left[\mathrm{hm}^{2}\right]}\end{array}$ & $\begin{array}{c}V \\
{\left[\mathrm{dam}^{3}\right]}\end{array}$ & $\begin{array}{l}Z_{\max } \\
{[\mathrm{m}]}\end{array}$ & $\begin{array}{c}\bar{Z} \\
{[\mathrm{~m}]}\end{array}$ & $\begin{array}{c}L \\
{[\mathrm{~m}]}\end{array}$ & $\begin{array}{c}B \\
{[\mathrm{~m}]}\end{array}$ & $\begin{array}{l}L_{e f} \\
{[\mathrm{~m}]}\end{array}$ & $\begin{array}{l}B_{\text {ef }} \\
{[\mathrm{m}]}\end{array}$ & $\begin{array}{l}S L \\
{[\mathrm{~m}]}\end{array}$ & L \\
\hline Błędne & $4^{\circ} 14.96^{\prime}$ & $8^{\prime}$ & 180.7 & 2.74 & 2.74 & 52.6 & 4.8 & 1.9 & 295 & 120 & 280 & 120 & 695 & \\
\hline Bocznel & '15.78' & $2^{\circ} 49$ & 27.6 & 9.17 & 9.17 & 43.2 & 3.9 & 1.3 & 1510 & 190 & 955 & 195 & 3300 & $m S C x m i$ \\
\hline Gulbin & `15.58' & $2^{\circ} 53$. & 47.7 & 7.38 & 7.38 & 254.7 & 9.1 & 3.5 & 465 & 200 & 440 & 205 & 110 & \\
\hline Hańcza* & •15.99' & $2^{\circ} 48.84^{\prime}$ & 227.5 & 303.56 & 303.56 & 118648. & 105.6 & 39.1 & 4680 & 1180 & 4060 & 1120 & 12600 & $p-m S C x m i$ \\
\hline Jaczno & '16.44' & $30^{\prime}$ & 63.9 & 0.64 & 40.64 & 980.6 & 25.7 & 9.8 & 1735 & 550 & 870 & 710 & 4955 & SCxmi \\
\hline Jegłówecz & $4^{\circ} 14.19^{\prime}$ & $22^{\circ} 52.74^{\prime}$ & 185.7 & 1.81 & 1.81 & 56.9 & 8.3 & 3.1 & 245 & 95 & 235 & 95 & 565 & SCxmi \\
\hline Jegłówek & $54^{\circ} 14.31^{\prime}$ & $22^{\circ} 53.36^{\prime}$ & 185.1 & 20.12 & 19.81 & 1835.2 & 27.7 & 9.9 & 990 & 395 & 785 & 405 & 2805 & $p S$ \\
\hline Kar & & & 161.0 & 25.26 & 25.26 & 1767.4 & 26.2 & 7.0 & 1015 & 430 & 950 & 435 & 2360 & \\
\hline Kluczysko & $54^{\circ} 13.99^{\prime}$ & $22^{\circ} 52.88^{\prime}$ & 186.4 & 3.67 & 3.67 & 199.7 & 13.8 & 5.4 & 375 & 155 & 335 & 155 & 950 & SC \\
\hline Kojle & & $22^{\circ}$ & 148.3 & 17.26 & 17.26 & 79.4 & 32.3 & 9.7 & 710 & 450 & 620 & 435 & 2095 & $x m i$ \\
\hline Kopane & ○14.79' & $22^{\circ} 54.35^{\prime}$ & 179.0 & 16.15 & 16.15 & 918.4 & 18.8 & 5.7 & 870 & 305 & 830 & 300 & 2105 & $m S C$ \\
\hline Krejwelek & $4^{\circ} 16.32^{\prime}$ & $22^{\circ} 55.33^{\prime}$ & 146.4 & 8.76 & 8.76 & 249.3 & 5.5 & 2.8 & 615 & 255 & 565 & 215 & 1535 & Lmi \\
\hline Linówek & '13.44' & $22^{\circ} 50$ & 199.7 & 2.85 & 2.85 & 67.6 & 5.9 & 2.4 & 245 & 160 & 240 & 155 & 640 & $p S C x n$ \\
\hline Okrągłe & ${ }^{\circ} 15.97 '$ & $22^{\circ} 54.42^{\prime}$ & 146.9 & 15.03 & 15.03 & 645.9 & 7.4 & 4.3 & 660 & 350 & 650 & 350 & 1575 & pLmi \\
\hline Perty & & & 148.3 & 19.51 & 19.51 & 1446.2 & 32.6 & 7.4 & 1000 & 410 & 795 & 395 & 2765 & Cxme \\
\hline Pogor & $46^{\prime}$ & $22^{\circ}$ & 36.4 & 5.79 & 5.79 & 340.8 & 17.6 & 5.9 & 490 & 150 & 465 & 150 & 1140 & $m S C$ \\
\hline Postawelek & $54^{\circ} 17.01^{\prime}$ & $22^{\circ} 56.64^{\prime}$ & 145.7 & 3.35 & 3.35 & 67.9 & 4.0 & 2.0 & 245 & 198 & 245 & 198 & 675 & Lmi \\
\hline Przecho & & $22^{\circ} 55.63^{\prime}$ & 146.0 & 23.89 & 23.89 & 747.2 & 5.4 & 3.1 & 865 & 580 & 810 & 530 & 2240 & $p L m i$ \\
\hline Purwin & $54^{\circ} 16.83^{\prime}$ & $22^{\circ} 53.49^{\prime}$ & 149.0 & 1.41 & 1.41 & 38.9 & 4.3 & 2.8 & 155 & 120 & 155 & 120 & 435 & $\mathrm{mCme}$ \\
\hline Szurpiły & $54^{\circ} 13.77^{\prime}$ & $22^{\circ} 53.86^{\prime}$ & 182.8 & 85.29 & 84.35 & 9450.8 & 47.1 & 11.2 & 2170 & 680 & 1510 & 940 & 7505 & Cxmi \\
\hline Udziejek & $54^{\circ} 15.20^{\prime}$ & $22^{\circ} 53.35^{\prime}$ & 153.6 & 7.01 & 7.01 & 230.7 & 6.9 & 3.3 & 370 & 300 & 370 & 300 & 1060 & $m L m i$ \\
\hline Wodziłki & $54^{\circ} 14.49^{\prime}$ & $22^{\circ} 50.84^{\prime}$ & 175.5 & 3.73 & 3.73 & 115.7 & 5.4 & 3.1 & 295 & 145 & 290 & 145 & 755 & L-Cmi \\
\hline
\end{tabular}

* - data for Lake Hańcza according to Popielarczyk et al. (2015). 

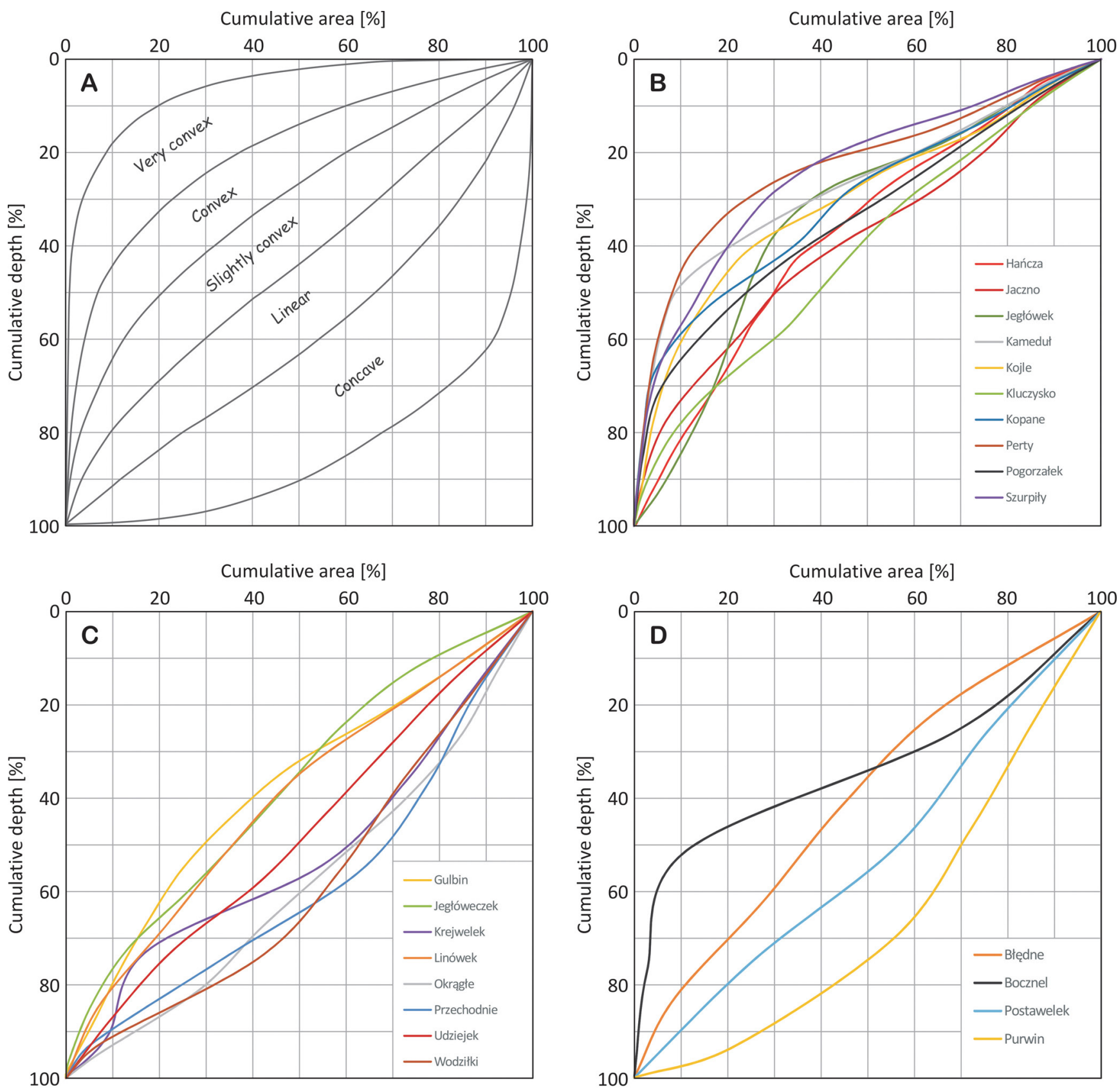

Fig. 3. Terminology and class limits for the classification system of lake basin forms according to Håkanson (1977b, 1981) - A; relative bathymetric curves for lakes deeper than $10 \mathrm{~m}-\mathrm{B}$; relative bathymetric curves for lakes with a maximum depth in the range of 5-10 $\mathrm{m}-\mathrm{C}$; relative bathymetric curves for shallow lakes with a maximum depth less than $5 \mathrm{~m}-\mathrm{D}$

\section{Discussion}

Morphometric parameters describing the size and shape of lake basins play an important role in explaining most abiotic and biotic phenomena and processes occurring in lakes (Wetzel 2001). Physical dimensions of lakes (area, depth, shoreline length, volume) are also used for their typology, assessment of lake resistance to the catchment impact, assessment of acceptable and critical loads of nutrients, and finally estimating water resources in the catchment or region. Practical use of morphometric characteristics in limnological research and lake management requires, above all, accurate and reliable data on the underwater lake topography. This demand is particularly important in relation to the areas of outstanding natural values covered by various forms of legal protection.

The use of a sonar equipped with a GPS receiver for bathymetric surveys significantly increases the ac- 
curacy and density of soundings. Application of a sonar in measurement of lake depth enabled the development of high-quality bathymetric maps, which are in turn starting material for the calculation of the fundamental morphometric characteristics of the studied lakes. The density of depth probing ranged from 318 to 1177 (average 621) soundings per hectare in the case of lakes smaller than $10 \mathrm{hm}^{2}$, and from 145 to 574 (average 291) soundings per hectare for lakes larger than $10 \mathrm{hm}^{2}$. The density of the measurements was two orders of magnitude greater than that used by the IRS and OBiKŚ in Suwałki, both of which used manual sounding from ice in nodes of grid squares of $20 \times 20$ to $50 \times 50 \mathrm{~m}$. In the measurement from ice the density of probing did not exceed a few or a few dozen soundings per hectare. Furthermore, the hydroacoustic method carried out by the IMGW in the 1980s was very schematic. During the measurements only one longitudinal profile and a few transverse profiles were made. In the search for maximum depth, the measurements were further concentrated (Jańczak 1996). For lakes surveyed in this way, the mean depth was determined from empirical formulas (Jańczak and Sziwa 1984), while the volume was the product of the surface area and mean depth. Thus, the images of the underwater topography of lakes were generally very simplified, and the calculated morphometric parameters approximate.

With regard to water resources of the SPK, the aggregated volume of the lakes obtained on the basis of the existing measurements was found to be slightly larger than that in the light of current research. In the case of lakes larger than $10 \mathrm{hm}^{2}$, the maximum difference was $703.7 \mathrm{dam}^{3}$, or less than $0.5 \%$ of the current total volume of the lakes. Additionally, the summary of surfaces differed by less than $0.4 \%$ (Figs $4 \mathrm{~A}-\mathrm{B}$ ). The results of the current measurements also helped determine the water resources of the four previously unstudied lakes. Their total volume was $548.0 \mathrm{dam}^{3}$, and more than $62 \%$ of these resources are found in Lake Pogorzałek. With a volume of $340.8 \mathrm{dam}^{3}$, Lake Pogorzałek proved to be one of the richest in terms of water, and also one of the deepest lakes of the SLP.

These observations suggest the apparent accuracy and reliability of the previously produced bathymetric maps of the SLP lakes. However, the summary of the research results for individual lakes no longer indicates such large compliance.

The surfaces of the SLP lakes cited so far differ significantly from those set forth in these studies. Relative differences in the surface area range from -14.1 to $9.1 \%$. In the case of six lakes their surfaces were understated by more than $10 \%$ in relation to the results of the current measurements (Fig. 5A). The most common cause of errors in determining lake areas was set- ting the shoreline course during ongoing winter depth measurements. Determining the actual water-land boundary when the lakeshore zone is covered by snow and ice will obviously invite imprecision (Udziejek, Linówek, Jegłóweczek). In the case of Lake Bocznel the differences stem from a simplified representation of the shoreline of the strongly overgrown lake on the topographic map, while the rules determining the course of the shoreline of Lake Kojle are unknown (Mickiewicz 1977), and thus the differences are difficult to interpret.

In the case of lake volume, the differences appear to be significantly greater than the differences in their surface area. The revealed relative discrepancies in the volumes of the SLP lakes fall into a very wide range, from -32.2 to $35.3 \%$. These disparities mainly result from simplified measuring techniques, which do not provide high accuracy and reliable bottom relief projection, especially in the varied lake basin bottom topography. A particular example is Lake Bocznel. Its volume set by the IRS $\left(324.1 \mathrm{dam}^{3}\right)$ and IMGW (165.0
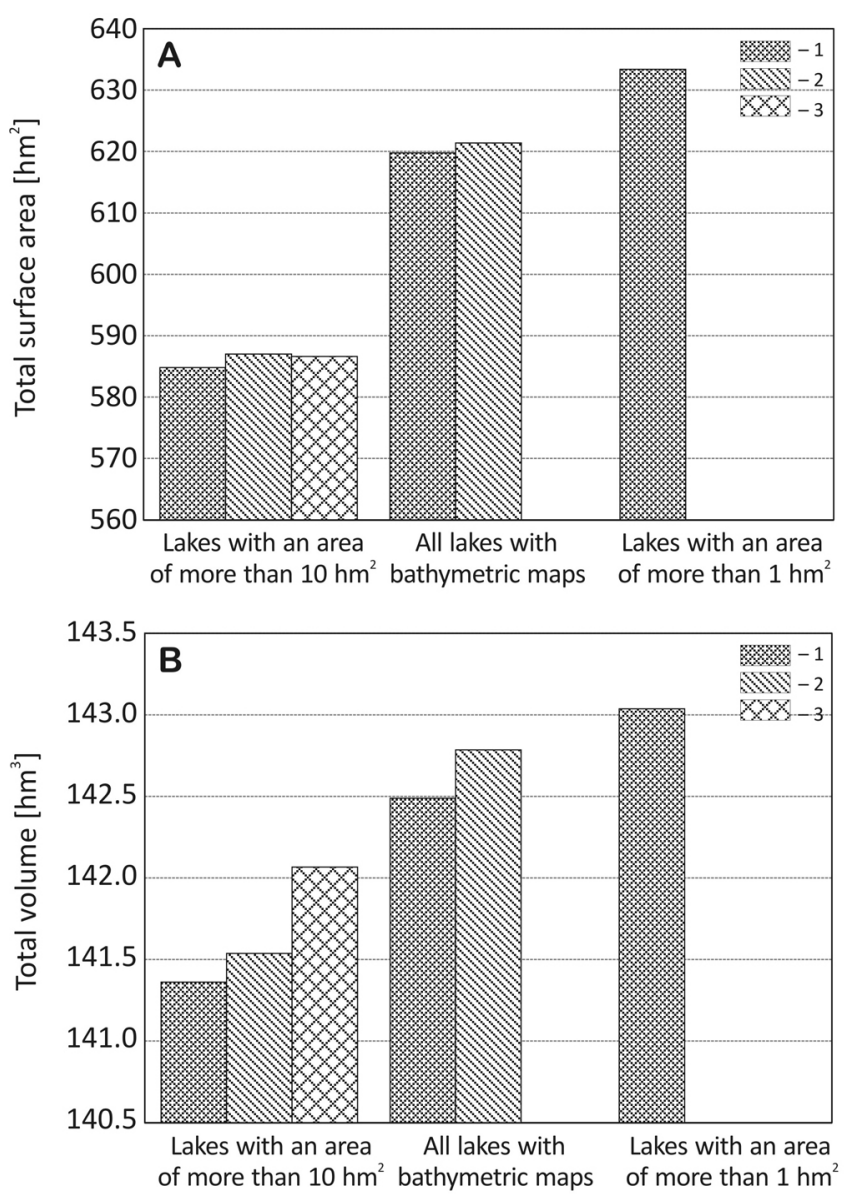

Fig. 4. Comparison of the aggregate surface areas (A) and volumes (B) of the Suwałki Landscape Park lakes according to this study and previous data sources. Explanation: 1 - this study, 2 - IRS and OBiKŚ (unpubl.), 3 - Jańczak (1999) 
dam $^{3}$ ) not only significantly differs from that calculated on the basis of current measurements (Fig. 5), but the difference is nearly double. According to the IRS measurements, Lake Bocznel had a maximum depth of 4.3 $\mathrm{m}$, while according to the IMGW measurements only $1.8 \mathrm{~m}$ (Jańczak 1999). The maximum depth measured in Lake Bocznel in 2013 was $3.9 \mathrm{~m}$.

In the IMGW calculations of lake volume the vital issue was the proper determination of the maximum depth of the lakes during the surveying work. This parameter was used for the estimation of mean depth and then for volume calculations. Significant differ- ences found in the volume of the lakes surveyed by the IMGW, and the results of the current measurement are a simple consequence of errors in assessing the maximum depth of the lakes. The maximum difference of $9.6 \mathrm{~m}$ was found in Lake Jegłówek (Tables 1-2). The mean absolute error (MAE) of the maximum depths measured by the IMGW relative to current measurements was $3.1 \mathrm{~m}$. In relation to the IRS measurement this error was only $0.8 \mathrm{~m}$. After taking into account the maximum depth correction of some of the lakes made by Mickiewicz (1977), the error value is reduced by half (0.4). Respecting the IRS, the biggest mismatch of the
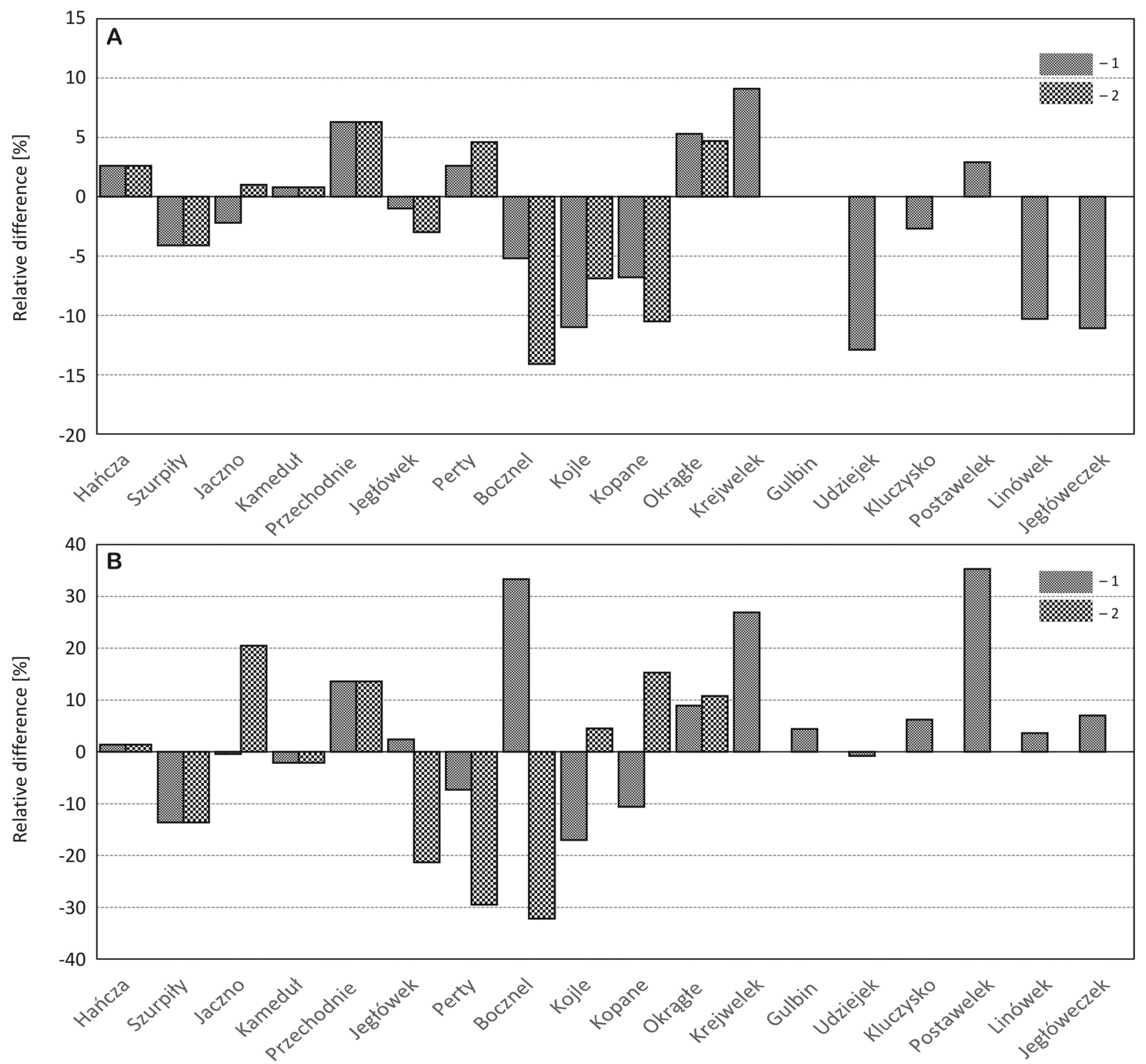

Fig. 5. Percentage differences between the old values of surface area (A) and volume (B) of the Suwałki Landscape Park lakes relative to the results of the new surveys. Explanation: 1 - IRS and OBiKŚ (unpubl.), 2 - Jańczak (1999) 
maximum depth $(2.9 \mathrm{~m})$ was found in Lake Hańcza (Popielarczyk et al. 2015). In the light of the latest bathymetric measurements, the maximum depth of Lake Hańcza, the deepest lake in Poland, is now $105.6 \mathrm{~m}$.

Another issue is the method adopted by the IMGW to calculate the mean depth of lakes. In order to determine the mean depth statistical formulas were used, where the mean depth is described as a function of maximum depth. Detailed analysis of the SLP lakes showed that the lakes present clearly visible morphometric individuality. That individuality is expressed not only against the entire population of the lakes of Northern Poland, but also in relation to the lakes of the Lithuanian Lakeland, the region in which the Suwałki Landscape Park is located. In individual size classes (Majdanowski 1954) the SLP lakes show much greater volume and mean depth than the same sized lakes of Northern Poland or the Lithuanian Lakeland (Fig. 6). These disparities are particularly pronounced in lake classes with surface areas greater than $10 \mathrm{hm}^{2}$. In the specific morphometric conditions of some groups of lakes (such a specific group are the SLP lakes), considered even at the regional level or in lake size classes, connections of the type $\bar{z}=f\left(z_{\text {max }}\right)$ can generate additional errors.

Comparative analysis of the main parameters of the lake size (area, volume, depth) determined on the basis of previous and current measurements of the morphology of the SLP lakes showed that the smallest disparities were observed with respect to the data obtained by the IRS. The IMGW bathymetric meas-

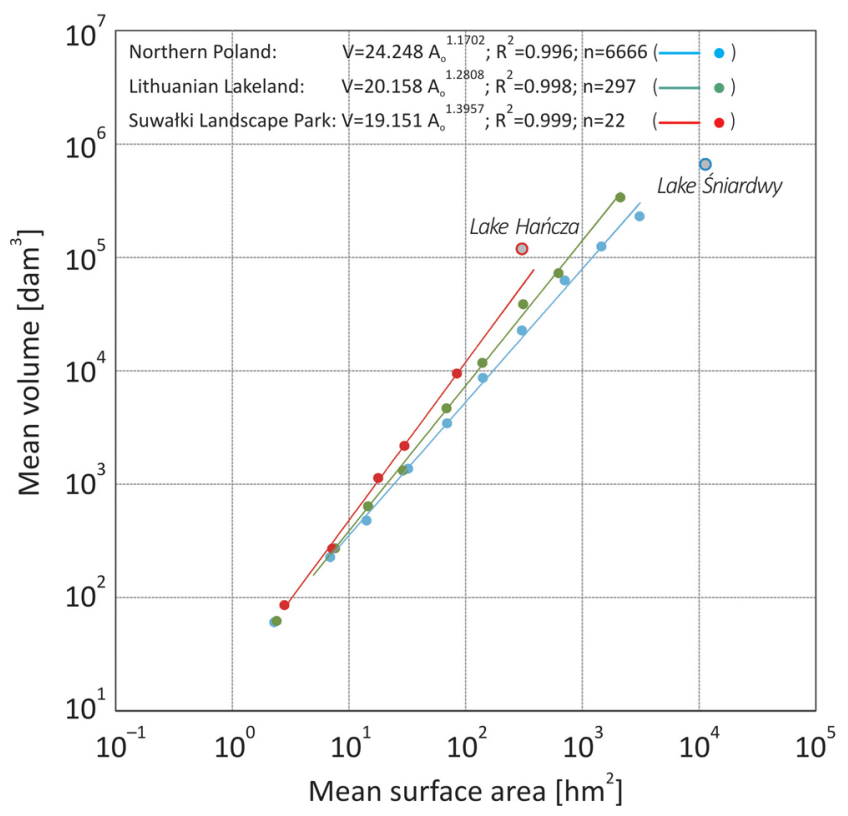

Fig. 6. Relationships between mean surface area and mean volume in lake size classes established for Northern Poland, Lithuanian Lakeland and Suwałki Landscape Park urements were, however, subject to substantial errors, and morphometric parameters determined on their basis are only approximate. The degree of approximation is, however, varied. The perfunctory character of the IMGW morphometric data was indicated earlier by Choiński and Ptak (2014), who carried out their research in the Greater Poland-Kuyavian Lakeland.

In the overall ranking, the largest relative disparities $( \pm 10 \%)$ in the assessment of the volume of the SLP lakes were found in Lakes Szurpily, Przechodnie, Bocznel, Kojle, Kopane, Krejwelek and Postawelek - the IRS and OBiKŚ data; as well as Lakes Szurpiły, Przechodnie, Jaczno, Jegłówek, Perty, Bocznel, Kopane and Okrągłe - the IMGW data (Fig. 5). The greatest differences in volume, expressed in absolute terms, were recorded in the largest SLP lakes: Hańcza $\left(1716.1 \mathrm{dam}^{3}\right)$, Szurpiły $\left(1282.0 \mathrm{dam}^{3}\right)$, Jaczno $\left(816.4 \mathrm{dam}^{3}\right)$, Perty $\left(427.1 \mathrm{dam}^{3}\right)$, Jegłówek $\left(391.2 \mathrm{dam}^{3}\right)$ and Kojle $\left(286.2 \mathrm{dam}^{3}\right)$.

\section{References}

Bajkiewicz-Grabowska E., 1994, Charakterystyka fizycznogeograficzna i hydrograficzna Suwalskiego Parku Krajobrazowego (Physico-geographical and hydrographical characteristics of Suwałki Landscape Park), [in:] Hillbricht-Ilkowska A., Wiśniewski J.R. (eds), Jeziora Suwalskiego Parku Krajobrazowego. Związki z krajobrazem, stan eutrofizacji i kierunki rozwoju (Lakes of the Suwałki Landscape Park. Links with landscape, eutrophication and protection measures), Zesz. Nauk. Komit. „Człowiek i Środowisko" PAN 7: 15-31 (in Polish, English summary).

Blais J.M., Kalff J., 1995, The influence of lake morphometry on sediment focusing, Limnol. Oceanogr. 40(3): 582-588.

Borowiak D., 2011, Właściwości optyczne wód jeziornych pomorza (Optical properties of the Pomeranian lakes), Wydaw. UG, Gdańsk, 275 pp. (in Polish, English summary).

Byczkowski A., 1980, Bilans wodny jeziora położonego w obszarze źródliskowym zlewni, na przykładzie jeziora Jaczno na Pojezierzu Suwalskim (Water balance of a lake situated in a headwater catchment. A case study of Lake Jaczno in Suwałki Lakeland), [in:] Friedrich M. (ed.) Stosunki wodne w zlewniach rzek Przymorza i dorzecza Dolnej Wisły ze szczególnym uwzględnieniem gospodarki wodnej jezior (Water conditions of river catchments in the Coastal Region and the Lower Vistula basin with particular emphasis on lake water management), Referaty - Cz. 2, Mat. Sesji Nauk.-Tech., 23-24 październik 1980, Słupsk: 257-266 (in Polish).

Choiński A., 1991, Katalog jezior Polski. Część druga: Pojezierze Mazurskie (Catalogue of Polish lakes. Part 2: Masurian Lakeland) Wydaw. Nauk. UAM, Poznań, 157 pp. (in Polish).

Choiński A., Skowron R., 1998, Najgłębsze jeziora Niżu Polskiego w świetle najnowszych pomiarów głębokościowych 
(The deepest Polish Lowlands lakes in light of new measurements), Czas. Geogr. 69(3-4): 339-343 (in Polish, English summary).

Choiński A., Ptak M., 2015, Najnowsze sondowania wybranych jezior Pojezierza Wielkopolsko-Kujawskiego The latest surveys of selected lakes of the Greater PolandCuyavian Lakeland), Bad. Fizjogr. A65: 55-63 (in Polish, English summary).

Eberly W.R., 1964, Further studies on the metalimnetic oxygen maximum, with special reference to its occurrence throughout the world, Invest. Indiana Lakes Streams 6: 103-139.

Gieysztorowa I., 1953, Katalog jezior polskich. Cz. 13: Jeziora suwalskie (Catalogue of Polish lakes. Part 13: Suwałki Region lakes), Biul. Geogr. PTG 15: 1-28.

Gorhan E., 1964, Morphometric control of annual heat budgets in temperate lakes, Limnol. Oceanogr. 9(4): 525-529.

Gorhan E., Boyce F.M., 1989, Influence of lake surface area and depth upon thermal stratification and depth of the summer thermocline, J. Great Lakes Res. 15(2): 233-245.

[GUGiK] Główny Urząd Geodezji i Kartografii (National Council of Geodesy and Cartography), 2006, Nazewnictwo geograficzne Polski. Tom I. Hydronimy, Część 2: Wody stojące (Geographical names of Poland. Vol. I. Hydronyms, Part 2: Standing waters), Wydaw. GUGiK, Warszawa, 410 pp (in Polish).

Guildford S.J., Hendzel L.L., Kling H.J., Fee E.J., Robinson G.G.C., Hecky R.E., Kasian S.E.M., 1994, Effects of lake size on phytoplankton nutrient status. Can. J. Fish. Aquat. Sci. 51(12): 2769-2783.

Håkanson L., 1977a, The influence of wind, fetch and water depth on the distribution of of sediments in Lake Vanern, Can. J. Earth Sci. 14(3): 397-412.

Håkanson L., 1977b, On lake form, lake volume and lake hypsographic survey, Geogr. Ann. Phys. Geogr. 59A(12): $1-29$.

Håkanson L., 1981, A manual of lake morphometry, Springer-Verlag, Berlin-Heidelberg-New York, 78 pp.

Jańczak J. (ed.), 1996, Atlas jezior Polski. Tom 1: Jeziora Pojezierza Wielkopolskiego i Pomorskiego w granicach dorzecza Odry (The atlas of Polish lakes. Vol. 1: Wielkopolska and pomeranian Lake Districts in the Odra River basin)), Bogucki Wydaw. Nauk., Poznań: 268 pp (in Polish, English summary).

Jańczak J. (ed.), 1999, Atlas jezior Polski. Tom 3: Jeziora Pojezierza Mazurskiego i Polski południowej (The atlas of Polish lakes. Vol. 3: Masurian lakes and the southern part of Poland), Bogucki Wydaw. Nauk., Poznań: 240 pp (in Polish, English summary).

Jańczak J., Sziwa R., 1984, Związek między głębokościami największymi a średnimi jezior (Relation between maximum and medium depths of lakes)), Prz. Geofiz. 29(1):65-74 (in Polish, English summary).

Johnson N.M., Eaton J.S., Richey J.E., 1978, Analysis of five north American lakes ecosystems. II. Thermal energy and mechanical stability, Verh. Int. Ver. Limnol. 20: 562-567.
Jozsa V., Tatrai I., Gyore K., Kozłowski J., 2008, Profile batymetryczne jeziora Hańcza (Bathymetric profiles of the Lake Hańcza), [in:] Kozłowski J., Poczyczyński P., Zdanowski B. (red.) Środowisko i ichtiofauna jeziora Hańcza (Environment and ichthyofauna of Lake Hańcza), Wydaw. IRS, Olsztyn: 43-58 (in Polish).

Kołodziejczyk A.,1994, Mięczaki słodkowodne Suwalskiego Parku Krajobrazowego (The freshwater molluscs of Suwałki Landscape Park), [in:] Hillbricht-Ilkowska A., Wiśniewski J.R. (eds), Jeziora Suwalskiego Parku Krajobrazowego. Związki z krajobrazem, stan eutrofizacji i kierunki rozwoju (Lakes of the Suwałki Landscape Park. Links with landscape, eutrophication and protection measures), Zesz. Nauk. Komit. „Człowiek i Środowisko” PAN 7: 243-65 (in Polish, English summary).

Lange W., 1986, Fizyczno-limnologiczne uwarunkowania tolerancji systemów jeziornych Pomorza (Physico-limnologic conditioning of the Pomeranian lake systems tolerance), Zesz. Nauk. UG, Rozpr. Monogr. 79: 3-177 (in Polish, English summary).

Lathrop R.C., Lille R.A., 1980, Thermal stratification of Wisconsin lakes, Trans. Wis. Acad. Sci. Arts Lett. 68: 90-96.

Lerman A., Hull A.B., 1987, Background aspects of lake restoration: Water balance, heavy metal content, phosphorus homeostasis, Schweiz. Z. Hydrol. 49(2): 148-169.

Majdanowski S., 1954, Zestawienie ogólne jezior Polski, Biul. Geogr. 4: 3-21

Mickiewicz B., 1977, Zmiany poziomu wód gruntowych a środowisko przyrodnicze (Changes in the groundwater level against the natural environment), Wyd. Katalogów i Cenników, Warszawa, 88 pp. (in Polish).

Nõges T., 2009, Relationships between morphometry, geographic location and water quality parameters of European lakes, Hydrobiologia 633: 33-43.

Nürnberg K., 1995, Quantifying anoxia in lakes, Limnol. Oceanogr. 40(6): 1100-1111.

Ozimek T., Rybak I.,1994, Typologia florystyczna drobnych bezodpływowych zbiorników Suwalskiego Parku Krajobrazowego Floristic typology of small enclosed bodies of water in Suwałki Landscape Park), [in:] HillbrichtIlkowska A., Wiśniewski J.R. (eds), Jeziora Suwalskiego Parku Krajobrazowego. Związki z krajobrazem, stan eutrofizacji i kierunki rozwoju (Lakes of the Suwałki Landscape Park. Links with landscape, eutrophication and protection measures), Zesz. Nauk. Komit. „Człowiek i Środowisko" PAN 7: 151-162 (in Polish, English summary).

Pasławski Z., 1975, Typologia hydrologiczna jezior Pojezierza Wielkopolskiego (Hydrological typology of lakes in Great Poland Lakeland), Prz. Geofiz. 20(4): 271-280 (in Polish, English summary).

Patalas K., 1960, Mieszanie wiatrowe jako czynnik określający intensywność krążenia materii w różnych morfologicznie jeziorach okolic Węgorzewa (Mixing of wind as a factor determining the intensity of circulation of matter in morphologically different lakes surrounding Węgorzewo), 
Rocz. Nauk Rol. B 77(1):223-242 (in Polish, English summary).

Pietkiewicz S., 1928, Pojezierze Suwalszczyzny zachodniej. Zarys morfologii lodowcowej (Lakeland of the western part of Suwałki region. Outline of glacial landforms), Prz. Geogr. 8(3-4):168-222 (in Polish, French summary).

Popielarczyk D., Templin T., 2014, Application of integrated GNSS/Hydroacoustic measurements and GIS geodatabase models for bottom analysis of Lake Hancza: the deepest inland reservoir in Poland, Pure Appl. Geophys. 171: 997-1011.

Popielarczyk D., Templin T., Łopata M., 2015, Using the geodetic and hydroacoustic measurements to investigate the bathymetric and morphometric parameters of Lake Hancza (Poland), Open Geosci. 7: 854-869.

Rühle E., 1932, Jezioro Hańcza na Pojezierzu Suwalskiem (Lake Hańcza in the Suwałki Lakeland), Wiad. Sł. Geogr. 4: 1-26.

Stangenberg M., 1936, Szkic limnologiczny na tle stosunków hydrochemicznych Pojezierza Suwalskiego. Suchar i Jezi- orko jako stadjum przejściowe zanikania jezior (Limnological study against the hydrochemical conditions of the Suwałki Lakeland. Lakes Suchar and Jeziorko as a transitional stage of lake disappearance), Pr. Inst. Bad. Lasów Państw. A 19: 1- 85 (in Polish, German summary).

Stangenberg M., 1937, Charakterystyka limnologiczna jezior grupy Kleszczowickiej i Hańczańskiej na pojezierzu Suwalszczyzny (Limnological characteristics of the Kleszczówek and Hańcza lake groups in the Suwałki Lakeland), Pr. Inst. Bad. Lasów Państw. A 23: 1-17.

Stefanidis K., Papastergiadou E., 2012, Relationships between lake morphometry, water quality, and aquatic macrophytes in Greek lakes, Fresenius Environ. Bull. 21(10A) 3018-3026.

Śledziński J., 1928, O jeziorach suwalskich (Lakes of the Suwałki region), Prz. Rybacki 1(9): 340-349 (in Polish).

Wetzel R.G., 2001, Limnology. Lake and river ecosystems, Academic Press, San Diego, 1066 pp. 